\title{
Modern possibilities with early laboratory diagnosis of periprosthetic osteolysis predating aseptic loosening in total hip arthroplasty (literature review)
}

\author{
S.V. Bragina
}

Northern State Medical University, Arkhangelsk, Russia

Implant survival is a very important outcome measure of surgical treatment of patients with severe degenerative joint disease in the hip. The aim of this review is to summarize the present knowledge on the possibilities for earlier laboratory diagnosis of osteolysis and prognostic approaches to prevent aseptic loosening of prosthetic implants. Results Periprosthetic osteolysis is often seen as an early sign of an adverse event associated with the development of unstable total hip arthroplasty (THA). A lot of data support the concept of osteolysis as a condition caused by biomechanical stresses, surgery specific factors, preoperative decrease and postoperative loss of bone mineral density, vascular impairment and chronic inflammation. Hemostasiological, biochemical and immunological parameters of patients were explored before and after THA. Surgical intervention was treated as the cause of secondary immunodeficiency, and results of the recovery period evaluated with regard to the extent to which immunodeficiency appeared to be compensated. Dynamics in stress related bone remodeling around the implant was found to be be a marker for early detection of osteolysis and prediction of aseptic loosening of THA, as well as control over the "target" of drug exposure. Conclusion Literature review suggests that there is a common understanding of the pathogenesis of osteolysis and the development of aseptic loosening of THA, and there is scanty data on the laboratory markers for early diagnosis and prediction of the complication that would require further study.

Keywords: total hip arthroplasty, osteolysis, endoprosthesis loosening, prediction

\section{INTRODUCTION}

Since the time Sir John Charnley designed a hip prosthesis total hip arthroplasty (THA) has evolved into one of the most successful orthopedic procedures performed today. There has been an increase in the number of primary and revision THAs performed worldwide [1, 2]. Aseptic loosening is a major complication of joint replacement and it is important to identify factors potentially associated with the adverse event [3-
8]. Despite the large number of publications on complications following arthroplasty and extensive discussions in orthopaedic forums, controversies exist regarding potential prognosis and prophylaxis of adverve events of THA [9-15].

The aim of this review is to summarize the present knowledge on the possibilities for earlier laboratory diagnosis of osteolysis and prognosis to prevent aseptic loosening of prosthetic implants.

\section{RESULTS}

While the global medial research efforts focus on different aspects of osteoarthritis orthopaedic and trauma surgeons continue to perform radical procedures replacing the native joint with endoprosthesis for severe conditions. Total joint arthroplasties have revolutionized the care of patients with end-stage joint disease, leading to pain relief, functional recovery, and substantial improvement in quality of life. The longer patients use endoprosthesis the higher is the risk of implant loosening [16-20]. J.B. Meding et al. reviewed 8331 primary THAs to determine the greatest risk of failure across time. The average time to failure was 9.2 years, and $75 \%$ of failures occurred by 13 years. The most common failure mechanisms were due to the cup (5.0 \%), cup and stem (1.7 \%) and the stem (0.4\%). Based on the most common failure mechanisms, the authors recommended to evaluate patients at 6 months, 1 year, 3 years, 7 years, 10 years, 12 years, 18 years, and 25 years postoperatively [21].

Aseptic loosening occurs in dynamics at a long term with the implant being stable and osteointegrated over a protracted period that can be followed by bone resorption at the periprosthetic site with the bone being replaced by spongious connective tissue with infiltrated macrophages and implant-derived wear particles. Aseptic loosening secondary to periprosthetic osteolysis has been accepted as one of the leading causes of revision procedures in 2/3 patients with previous joint arthroplasty [22-24]. The impact of periprosthetic osteolysis on THA ranges between $1 \%$ and $40 \%$ of all THA revisions [25-27]. A major concern in periprosthetic osteolysis is that patients may have no clinical manifestations, no suggestion of

Bragina S.V. Modern possibilities with early laboratory diagnosis of periprosthetic osteolysis predating aseptic loosening in total hip arthroplasty (literature review). Genij Ortopedii, 2020, vol. 26, no 2, pp. 261-265. DOI 10.18019/1028-4427-2020-26-2-261-265 
any sign of infection, effectively remaining completely asymptomatic [28-31]. Although Sir John Charnley suggested that aseptic loosening could be caused by subclinical infection, recently it has been recognized that aseptic joint replacement loosening cannot be driven by bacterial infection, and underlying mechanisms are being searched [32]. Aseptic loosening may occur due to the biological response of the bone to fluctuating intraarticular fluid pressure, stress shielding and micromotion at the bone-implant interfaces [33]. The process referred to as particle disease often leads to joint loosening and implant failure [23, 28, 30]. Wear of endoprosthetic components gradually sets in due to mechanical surface interactions between bearing surfaces of the implants and the bone with a lot of implant-derived wear particles migrating into the pseudosynovial fluid and the surrounding tissues. The characterization of wear particles (size, shape, chemical composition) ranges depending on the origin and individual response of the body.

Those are mostly ultra-high molecular weight polyethylene (UHMWPE) wear particles generated from the bearing implant surfaces with the metal prosthetic femoral head and a polyethylene liner being involved in the pathways with a mean linear wear rate of $0.1 \mathrm{~mm} /$ year forming numerous UHMWPE particles [29]. Metal-to-metal implants have less wear than metal-to-polyethylene implants but still with release of numerous nano-sized metal particles [34]. Additional sources of wear include increased shattering and greater fragmentation of polymethylmethacrylate particles, metallic or ceramic particles released from bearing surfaces or modified implant surfaces [28, 30, 35]. The particles released into pseudosynovial fluid are accumulated in the surrounding tissues under the influence of hydrodynamic forces being generated in the fluid with every step and the environment appears to be densely packed with biomaterials of different wear particles. UHMWPE particles tended to exhibit many different morphologies over a number of size ranges. Particles of UHMWPE are assumed to be spheroids with the diameter of 0.1 to $1.0 \mu \mathrm{m}$ (mean diameter ranging from 0.5 to $0.7 \mu \mathrm{m}$ ) [36, 37]. It has been recognized that wear debris stimulates an innate host immune response leading to chronic low-grade inflammation and finally, to osteolysis [28-31, 34]. The foreign body response with macrophages and foreign body giant cells is identified leading eventually to predominance of osteoclasts at bone-soft tissue interface. Biomechanical and tribological aspects are considrered to be crucial in pathogenesis of implant failure. Those include functional overloading, surgery specific failures, preoperative decrease and postoperative loss of bone mineral density, vascular impairment and slow blood flow, hypercoagulation, injury to vascular wall secondary to vasoconstriction deteriorating in the operated limb postsurgery, synovitis, generated wear debris in the tissues having a key role in the progression of the disease with numerous proinflammatory cytokine secretion $[28,29]$. Surgical aggressive approach in arthroplasty includes volume of intervention, the traumatic profile, blood loss and can cause secondary immunodeficiency and/or aggravate the patient's condition [38].

Biological interactions are explored with an implant's integration in the human body in addition to the aspects of mechanical wear of endoprosthetic components, and biochemical reactions of the symbiosis can be unpredictable. Endoprosthesis is placed into aggressive and dynamic physiological environment and introduces mechanical loading causing non-specific reactions and launching specific immune mechanisms [34]. Immunopathological features and changes in immune function during perioperative period are resposible for postoperative rehabilitation and the outcome. E.V.Gladkova et al., I.V.Chebotar focused on hemostasiological, biochemical and immunological tests examining peripheral blood films of patients preoperatively, at 4 to 5 months postsurgery, analyzing three leukocyte subpopulations (lymphocytes, monocytes, granulocytes) and immunophenotyping lymphocytes. Preoperative and postoperative blood test results indicated to expressed immune disorders in patients with osteoarthrosis of major joints of lower limbs. Postoperative changes in the blood tests exhibited humoral and cell-mediated immune deficiencies that were shown to interefere with adequate protective response to aggressive operative treatment with arthroplasty [39, 40]. E.V.Koryakina et al. explored preoperative immune status of patients and detected activation of proinflammatory cytokine (FNO $\alpha$, IL$1 \beta$, IL-6) associated with changes in concentration of anti-iflammatory cytokines (IL-4, IL-10). The authors suggested that preoperative lack of functional activity of T-helpers led to immune deficiency in patients with osteoarthrosis [41]. Low phagocytic activity of segmented neutrophils, high levels of T lymphocytes, $B$ lymphocytes and immunoglobulins were reported in revision THA cases [42-44].

L.A. Dmitrieva reported increased serum concentration of IgA and high level of proinflammatory cytokines produced in the peripheral blood cells of patients with severe dysplastic coxarthrosis that necessitated grouping of dysplastic coxarthrosis cases depending on severity and type of immunopathological reactions (conventionally compensated and 
subcompensated immunodeficiency). There was correlation observed between outcomes of surgical treatment and rehabilitation, and the extent to which immunodeficiency compensated.

The differences in the immune status and the pituitary-thyroidal link of the endocrine system noted in patients with compensated immunodeficiency facilitated favorable restorative period and minimal risk of postoperative adverse events. Alternately, patients with subcompensated immunodeficiency failed to hold a capacity to ramp up a protective mechanisms to surgical intervention and were identified as high-risk patients at different terms [45]. E.A.Volokitina et al. explored an immune response to surgical intervention in patients with hypoplastic coxarthrosis following THA and reported a slight increase in natural killer T cells (CD3+/ CD16+/CD56+) during the first postoperative month The authors detected the absence of profound disorders in the functional immune system with the favorable scenario with major humoral and cell-mediated immune parameters returning to baseline values at 18 to 21 days following THA. Moderate decrease in T cell count, imbalance of lymphocyte subpopulations, dysimmunoglobulinemia were noted with increase in weight-bearing on the operated limb at 3-to-6-month follow-up. Major cell-mediated immune parameters normalized and absolute numbers of T-helper cells and B-lymphocytes decreased at 7-to-12-month followup with no history of early and delayed postoperative complications. Normal levels of serum immunoglobulin of primary classes and circulating immune complexes were observed during the first year following THA [18].

Postoperative clinical manifestations of pain, limping, disturbed function of the operated joint without evident radiological signs of radiological implant loosening are indications for exploring biochemical parameters for diagnostic purposes. Biochemical criteria were offered for prognosis and early diagnosis of aseptic loosening prior to clinical manifestations [46]. E.A.Persova found that changes in the blood serum biochemical markers identified after THA anticipated alterations in bone mineral density with stress induced remodeling being detected at 1.5 to 3 months [47]. S.Yu.Istomin reported on comparative analysis of clinical and radiological findings and lipid peroxidation parameters establishing correlation between instability of endoprosthetic components and increased concentration of isopropanol soluble products of lipid peroxidation, decreased ascorbat induced lipid peroxidation, and found the metalloprotein concentration being responsible for control of postoperative period [48]. Specific bone metabolism markers have been widely used for early diagnosis and identification of risk factors leading to aseptic stem loosening in THA. A.E. Kearns et al. suggest that polypeptide growth factors and cytokines are involved in osteogenesis and bone resorption and receptor activator of nuclear factor kappa-B ligand (RANKL), a member of the tumor necrosis factor cytokine family, promotes terminal differentiation of osteoclast precursor cells and stimulates boneresorbing activity of mature osteoclasts [49]. Such cytokines and molecular factors as interleukins (IL) IL-1 $\beta$, IL-6, IL-8, IL-11, IL-17, tumor necrosis factoralpha (TNF- $\alpha$ ), macrophage inflammatory protein- $1 \alpha$, prostaglandin $\mathrm{E}$ and others can induce the synthesis of RANKL with bone marrow stromal cells including osteoblasts, T lymphocytes and B cells [50-56].

\section{DISCUSSION}

In this review we sought to summarize the present knowledge on the pathogenesis of periprosthetic osteolysis followed by the development of aseptic loosening of THA, possibilities for earlier laboratory diagnosis and prognosis of the adverse event. Being aware of the causes of aseptic loosening of THA as a chain of biomechanical reactions in the implant-host system, tribological implant characteristics, surgery specific failures specialists put forth their efforts in attempts to increase implant longevity. In addition, other factors can be involved in the pathogenesis of aseptic loosening in a particular case. There is a search of markers that would enable prediction of this threatening complication prior to THA or diagnosis of osteolysis as early as possible to prevent considerable bone loss. Hemostasiological, biochemical and immunological parameters of patients are explored before and after THA. There is an interest in studying specific features of immune status among phenotypical groups of patients with dysplastic and hypoplastic coxarthrosis. A surgical intervention is treated as the cause of secondary immunodeficiency, and results of the recovery period evaluated with regard to the extent to which immunodeficiency appears to be compensated. Potentially critical differences exist between biological mechanisms of primary, age-associated, post-traumatic and metabolic phenotypes of osteoarthritis. Dynamics in stress related bone remodeling of periprosthetic bone tissue can be a marker for early detection of osteolysis and prediction of aseptic loosening of THA, as well as control over the "target" of drug exposure. A prospective clinical observation of the anticipated development of 
the adverse event allows for timely detection of aseptic loosening. Further research on the sensitivity and specificity of the above parameters is required since, with the current knowledge of the pathogenesis of the chronic inflammation, they can be observed in a variety of nosologies including osteoarthrosis/osteoarthritis, systemic rheumatic diseases, metabolic syndromes, malignancies and other conditions.

\section{CONCLUSION}

Literature review suggests that there is a common understanding of the pathogenetic reactions at the bone-implant interface, the effects of particular biomechanical, tribological factors on the development of periprosthetic osteolysis followed by aseptic loosening of THA. Scanty data on the possibilities for early diagnosis and prediction of the complication require multidisciplinary research for the understanding of systemic approach to a range of conditions with identical markers involved in pathological reactions.

\section{REFERENCES}

1. Kurtz S., Ong K., Lau E., Mowat F., Halpern M. Projections of primary and revision hip and knee arthroplasty in the United States from 2005 to 2030. J. Bone Joint Surg. Am., 2007, vol. 89, no. 4, pp. 780-785. DOI: 10.2106/JBJS.F.00222.

2. Tikhilov R.M., Shubniakov I.I., Kovalenko A.N., Tsybin A.V., Sementkovskii A.V., Karpukhin A.S., Bashinskii O.A. Sovremennye tendentsii v ortopedii: revizii vertluzhnogo i bedrennogo komponentov [Current trends in orthopaedics: revisions of the acetabular and femoral components]. Travmatologiia i Ortopediia Rossii, 2012, no. 4 (66), pp. 5-16. (in Russian)

3. Akhtiamov I.F., Kolesnikov M.A., Shigaev E.S., Ziatdinov B.G., Gatina E.B., Korotkova O.S. Pervyi opyt sochetannoi tromboprofilaktiki pri artroplastike nizhnikh konechnostei: perspektivy i variant ispolzovaniia [The first experience of combined thromboprophylaxis in lower limb arthroplasty: prospects and variants of use]. Travmatologiia i Ortopediia Rossii, 2012, no. 1 (63), pp. 98-103. (in Russian)

4. Koulouvaris P., Sculco P., Finerty E., Sculco T., Sharrock N.E. Relationship between perioperative urinary tract infection and deep infection after joint arthroplasty. Clin. Orthop. Relat. Res., 2009, vol. 467, no. 7, pp. 1859-1867. DOI: 10.1007/s11999-008-0614-8.

5. Ruyssen-Witrand A., Gossec L., Salliot C., Luc M., Duclos M., Guignard S., Dougados M. Complication rates of 127 surgical procedures performed in rheumatic patients receiving tumor necrosis factor alpha blockers. Clin. Exp. Rheumatol., 2007, vol. 25, no. 3, pp. 430-436.

6. Shah K., Mohammed A., Patil S., McFadyen A., Meek R.M. Circulating cytokines after hip and knee arthroplasty: a preliminary study. Clin. Orthop. Relat. Res., 2009, vol. 467, no. 4, pp. 946-951. DOI: 10.1007/s11999-008-0562-3.

7. Volokitina E.A., Zaitseva O.P., Kolotygin D.A., Vishniakov A.A. Lokalnye intraoperatsionnye i rannie posleoperatsionnye oslozhneniia endoprotezirovaniia tazobedrennogo sustava [Local intraoperative and early postoperative complications after endoprosthetics of the hip]. Genij Ortopedii, 2009, no. 3, pp. 71-77. (in Russian)

8. Slobodskoi A.B., Osintsev E.Iu., Lezhnev A.G. Oslozhneniia posle endoprotezirovaniia tazobedrennogo sustava [Complications after the hip arthroplasty]. Vestnik Travmatologii i Ortopedii im. N.N. Priorova, 2011, no. 3, pp. 59-63. (in Russian)

9. Dorofeev Iu.L., Kalimullina A.F., Ptashnikov D.A., Linnik S.A., Tkachenko A.N., Zharovskikh O.S. Vozmozhnosti prognoza infektsionnykh oslozhnenii khirurgicheskogo vmeshatelstva pri endoprotezirovanii tazobedrennogo sustava [Scopes of predicting infectious complications of surgical interventions when performing the hip arthroplasty]. Vestnik Eksperimentalnoi i Klinicheskoi Khirurgii, 2014, vol. 7, no. 3, pp. 269-278. (in Russian)

10. Zhadenov I.I., Gnetnev A.M., Pozdniakova B.Ia., Babushkina I.V., Bairamkulov Sh.S., Kolmykova A.S., Antonycheva M.V., Puzrakova E.A. Vozmozhnost prognozirovaniia pozdnikh gnoinykh oslozhnenii posle endoprotezirovaniia tazobedrennogo sustava [The possibility to predict late purulent complications after the hip arthroplasty]. Travmatologiia i Ortopediia Rossii, 2002, no. 1, pp. 72-75. (in Russian)

11. Ilin A.A. Mamonov A.M., Karpov V.N., Zagorodnii N.V., Balberkin A.V. Primenenie matematicheskogo kompiuternogo modelirovaniia pri razrabotke i prognozirovanii biomekhanicheskogo povedeniia endoprotezov tazobedrennogo sustava [The use of mathematic computered modelling when developing and predicting the biomechanical behavior of the hip implants]. Vestnik Travmatologii $i$ Ortopedii im. N.N. Priorova, 2009, no. 3, p. 7-13. (in Russian)

12. Bongartz T. Elective orthopedic surgery and perioperative DMARD management: many questions, fewer answers, and some opinions ... J. Rheumatol., 2007, vol. 34, no. 4, pp. 653-655.

13. Dale H., Hallan G., Hallan G., Espehaug B., Havelin L.I., Engesaeter L.B. Increasing risk of revision due to deep infection after hip arthroplasty. Acta Orthop., 2009, vol. 80, no. 6, pp. 639-645. DOI: 10.3109/17453670903506658.

14. Gilson M., Gossec L., Mariette X., Gherissi D., Guyot M.H., Berthelot J.M., Wendling D., Michelet C., Dellamonica P., Tubach F., Dougados M., Salmon D. Risk factors for total joint arthroplasty infection in patients receiving tumor necrosis factor $\alpha$-blockers: a case-control study. Arthritis Res. Ther., 2010, vol. 12, no. 4, pp. R145. DOI: 10.1186/ar3087.

15. Santaguida P.L., Hawker G.A., Hudak P.L., Glazier R., Mahomed N.N., Kreder H.J., Coyte P.C., Wright J.G. Patient characteristics affecting the prognosis of total hip and knee joint arthroplasty: a systematic review. Can. J. Surg., 2008, vol. 51, no. 6, pp. 428-436.

16. Akhtiamov I.F. K voprosu o preemstvennosti v khirurgicheskom lechenii displasticheskogo koksartroza [On the problem of continuity in surgical treatment of dysplastic coxarthrosis]. Vestnik Travmatologii i Ortopedii im. N.N. Priorova, 2005, no. 2, pp. 70-75. (in Russian)

17. Makarov S.A., Makarov M.A., Pavlov V.P. Izmenenie mineralnoi plotnosti kostnoi tkani vokrug endoproteza u bolnykh s revmaticheskimi zabolevaniiami posle operatsii bestsementnogo totalnogo endoprotezirovaniia tazobedrennogo sustava [Change in bone tissue mineral density around the implant in patients with rheumatic diseases after performing the surgery of cementless total arthroplasty of the hip]. NauchnoPrakticheskaia Revmatologiia, 2006, no. 1, pp. 63-67. (in Russian)

18. Volokitina E.A., Chepeleva M.V. Immunologicheskaia dinamika u patsientov s gipoplasticheskim koksartrozom posle endoprotezirovaniia tazobedrennogo sustava [Immunological dynamics in patients with hypoplastic coxarthrosis after the hip endoprosthetics]. Genij Ortopedii, 2006, no. 2, pp. 35-39. (in Russian)

19. Rodionova S.S., Nuzhdin V.I., Morozov A.K., Kliushnichenko I.V., Turgumbaev T.N. Osteoporoz kak factor riska asepticheskoi nestabilnosti pri endoprotezirovanii tazobedrennogo sustava [Osteoporosis as risk factor of aseptic instability when performing the hip arthroplasty]. Vestnik Travmatologii i Ortopedii im. N.N. Priorova, 2007, no. 2, pp. 35-40. (in Russian)

20. Loskutov A.E., Naumenko L.Iu., Loskutov O.A., Oleinik A.E., Sinegubov D.A. Endoprotezirovanie tazobedrennogo sustava: monografiia [Arthroplasty of the hip: monograh]. Prof. Loskutov A.E., ed. Dnepropetrovsk, Lira, 2010, 344 p. (in Russian)

21. Meding J.B., Ritter M.A., Davis K.E., Farris A., Sueyoshi T. Meeting Increased Demand for THA and Follow-Up: An Actuarial Method to Determine Optimal Follow-Up Schedules. OJO Open Journal of Orthopedics, 2015, vol. 5, no. 8, pp. 245-252. DOI: 10.4236/ojo.2015.58033.

22. Harris W.H. Wear and periprosthetic osteolysis: the problem. Clin. Orthop. Relat. Res., 2001, no. 393, pp. 66-70.

23. Corbett K.L., Losina E., Nti A.A., Prokopetz J.J., Katz J.N. Population-based rates of revision of primary total hip arthroplasty: a systematic review. PLoS One, 2010, vol. 5, no. 10, pp. e13520. DOI: 10.1371/journal.pone.0013520.

24. Older J. Charnley low-friction arthroplasty: a worldwide retrospective review at 15 to 20 years. J. Arthroplasty, 2002, vol. 17, no. 6, pp. 675-680. 25. Prokhorenko V.M., Mashkov V.M., Mamedov A.A., Dolgopolov V.V. Osobennosti revizionnogo endoprotezirovaniia tazobedrennogo sustava pri 
prolabirovanii vertluzhnogo komponenta v polost malogo taza [Characteristic features of the hip revision arthroplasty in case of prolapsing the acetabular component into the small pelvis cavity]. Biulleten VSNTs SO RAMN, 2013, no. 6 (94), pp. 49-58. (in Russian)

26. Filippenko V.A., Tankut V.A., Masandika S.Kh. Oshibki i oslozhneniia pri endoprotezirovanii tazobedrennogo sustava i ikh profilaktika [Errors and complications in the hip arthroplasty and their prevention]. Vestnik Travmatologii i Ortopedii im. N.N. Priorova, 1998, no. 3, pp. (in Russian)

27. Herberts P., Malchau H., Garellick G. The Swedish National Hip Arthroplasty Register. Annual Report. Sweden, Gothenburg, Department of Orthopaedics Sahlgrenska University Hospital, 2003. Available at: www.jru.orthop.gu.se.

28. Holt G., Murnaghan C., Reilly J., Meek R.M. The biology of aseptic osteolysis. Clin. Orthop. Relat. Res., 2007, vol. 460, pp. $240-252$.

29. Purdue P.E., Koulouvaris P., Nestor B.J., Sculco T.P. The central role of wear debris in periprosthetic osteolysis. HSS J., 2006, vol. 2, no. 2, pp. $102-$ 113. DOI: $10.1007 / \mathrm{s} 11420-006-9003-6$.

30. Goodman S.B., Gómez Barrena E., Takagi M., Konttinen Y.T. Biocompatibility of total joint replacements: A review. J. Biomed. Mater. Res. A, 2009, vol. 90, no. 2, pp. 603-618. DOI: 10.1002/jbm.a.32063.

31. Gallo J., Goodman S.B., Konttinen Y.T., Raska M. Particle disease: biologic mechanisms of periprosthetic osteolysis in total hip arthroplasty. Innate Immun., 2013, vol. 19, no. 2, pp. 213-224. DOI: 10.1177/1753425912451779.

32. Learmonth I.D., Young C., Rorabeck C. The operation of the century: total hip replacement. Lancet, 2007, vol. 370, no. 9597, pp. 1508-1519. DOI: 10.1016/S0140-6736(07)60457-7.

33. Sundfeldt M., Carlsson L.V., Johansson C.B., Thomsen P., Gretzer C. Aseptic loosening, not only a question of wear: a review of different theories. Acta Orthop., 2006, vol. 77, no. 2, pp. 177-197.

34. Purdue P.E., Koulouvaris P., Potter H.G., Nestor B.J., Sculco T.P. The cellular and molecular biology of periprosthetic osteolysis. Clin. Orthop. Relat. Res., 2007, vol. 454, pp. 251-261.

35. Hallab N., Merritt K., Jacobs J.J. Metal sensitivity in patients with orthopaedic implants. J. Bone Joint Surg. Am., 2001, vol. 83, no. 3, pp. $428-436$.

36. Howling G.I., Barnett P.I., Tipper J.L., Stone M.H., Fisher J., Ingham E. Quantitative characterization of polyethylene debris isolated from periprosthetic tissue in early failure knee implants and early and late failure Charnley hip implants. J. Biomed. Mater. Res., 2001, vol. 58, no. 4, pp. 415-420.

37. Koseki H., Matsumoto T., Ito S., Doukawa H., Enomoto H., Shindo H. Analysis of polyethylene particles isolated from periprosthetic tissue of loosened hip arthroplasty and comparison with radiographic appearance. J. Orthop. Sci., 2005, vol. 10, no. 3, pp. 284-290.

38. Dmitrieva L.A., Lebedev V.F., Korshunova E.Iu. Oslozhneniia pri endoprotezirovanii tazobedrennogo sustava i sposoby ikh prognozirovaniia (obzor literatury) [Complications in the hip arthroplasty and ways of their predition]. Biulleten VSNTs SO RAMN, 2013, no. 2-1 (90), pp. 153-158. (in Russian)

39. Gladkova E.V., Kariakina E.V., Mamonova I.A., Fedonnikov A.S., Babushkina I.V., Norkin I.A., Puchinian D.M. Immunnaia reaktivnost kostnoi tkani u patsientov s osteoartrozom [Immune reactivity of bone tissue in patients with osteoarthrosis]. Meditsinskaia Immunologiia, 2015, vol. 17, Spets. Vyp. p. 329. (in Russian) Available at: https://elibrary.ru/item.asp?id=24499363.

40. Chebotar I.V. Mekhanizmy antibioplenochnogo immuniteta [Mechanisms of anti-biofilm immunity]. Vestnik RAMN, 2012, vol. 67, no. 12, pp. 2229. (in Russian)

41. Kariakina E.V., Norkin I.A., Gladkova E.V., Persova E.A., Matveeva O.V., Puchinian D.M. Strukturno-funktsionalnye osobennosti kostnoi tkani i tsitokiny krovi v norme I pri patologii sustavov [Structural and functional features of bone tissue and blood cytokines normally and in joint pathology]. Rossiiskii Fiziologicheskii Zhurnal im. I.M. Sechenova, 2014, vol. 100, no. 2, pp. 238-247. (in Russian)

42. Belova S.V., Mamonova I.A., Puchinian D.M., Babushkina I.V., Gladkova E.V., Adilov R.G. Vozmozhnost prognozirovaniia infektsionnovospalitelnykh oslozhnenii pri pervichnom endoprotezirovanii krupnykh sustavov [The possibility of predicting infectious-inflammatory complications in primary arthroplasty of large joints]. Saratovskii Nauchno-meditsinskii Zhurnal, 2017, vol.13, no. 3, pp. 715-719. (in Russian)

43. Filippenko V.A., Leonteva F.S., Morozenko D.V., Korzh I.V. Laboratornye diagnosticheskie marker pri otsenke sostoianiia bolnykh osteoartrozom, trebuiushchikh endoprotezirovaniia krupnykh sustavov (obzor literatury) [Laboratory diagnostic markers when evaluating the condition of patients with osteoarthrosis who need arthroplasty of large joints (review of the literature)]. Ortopediia, Travmatologiia i Protezirovanie, 2013, no. 2, pp. 122-126. (in Russian)

44. Voloshin V.P., Eremin A.V., Onoprienko G.A., Savitskaia K.I., Lekishvili M.V. Revizionnoe endoprotezirovanie tazobedrennogo sustava pri glubokoi infektsii [Revision arthroplasty of the hip in case of deep infection]. Almanakh Klinicheskoi Meditsiny, 2008, no. 18, pp. 35-44. (in Russian)

45. Dmitrieva L.A. Rol immunnykh $i$ endokrinnykh mekhanizmov v patogeneze displasticheskogo koksartroza $i$ zakonomernosti ikh izmenenii pri endoprotezirovanii tazobedrennogo sustava. Avtoref. Diss. dokt. med. nauk [Role of the immune and endocrine mechanisms in dysplastic coxarthrosis pathogenesis and regularities of their changes for the hip arthroplasty. Ext. Abstract Dr. med. sci. diss.]. Chita, 2009, 42 p. (in Russian)

46. Biomarkers Definitions Working Group. Biomarkers and surrogate endpoints: preferred definitions and conceptual framework. Clin. Pharmacol. Ther., 2001, vol. 69, no. 3, pp. 89-95. DOI: 10.1067/mcp.2001.113989.

47. Persova E.A. Osobennosti remodelirovaniia kostnoi tkani pri totalnom endoprotezirovanii tazobedrennogo sustava i ikh kliniko-laboratornaia otsenka. Avtoref. Diss. kand. med. nauk [Characteristic features of bone tissue remodeling in total arthroplasty of the hip and their clinical-andlaboratory assessment. Ext. Abstract Cand. med. sci. diss.]. Saratov, 2010, 27 p. (in Russian)

48. Istomin S.Iu. Prognozirovanie i diagnostika nestabilnosti posle totalnogo endoprotezirovaniia pri deformiruiushchem osteoartroze tazobedrennogo sustava (kliniko-biokhimicheskoe issledovanie). Avtoref. Diss. kand. med. nauk [Prediction and diagnostics of instability after total arthroplasty for deforming osteoarthrosis of the hip (clinical and biochemical study). Ext. Abstract Cand. med. sci. diss.]. Kurgan, 2009, 22 p. (in Russian)

49. Kearns A.E., Khosla S., Kostenuik P.J. Receptor activator of nuclear factor kappaB ligand and osteoprotegerin regulation of bone remodeling in health and disease. Endocr. Rev., 2008, vol. 29, no. 2, pp. 155-192.

50. Kwan Tat S., Padrines M., Théoleyre S., Heymann D., Fortun Y. IL-6, RANKL, TNF-alpha/IL-1: interrelations in bone resorption pathophysiology. Cytokine Growth Factor Rev., 2004, vol. 15, no. 1, pp. 49-60.

51. Leibbrandt A., Penninger J.M. RANK/RANKL: regulators of immune responses and bone physiology. Ann. N. Y. Acad. Sci., 2008, vol. 1143, pp. 123-150. DOI: 10.1196/annals.1443.016.

52. Quinn J.M., Gillespie M.T. Modulation of osteoclast formation. Biochem. Biophys. Res. Commun., 2005, vol. 328, no. 3, pp. 739-745.

53. Theill L.E., Boyle W.J., Penninger J.M. RANK-L and RANK: T cells, bone loss, and mammalian evolution. Annu Rev. Immunol., 2002, vol. 20, pp. 795-823.

54. Ryan M.R., Shepherd R., Leavey J.K., Gao Y., Grassi F., Schnell F.J., Qian W.P., Kersh G.J., Weitzmann M.N., Pacifici R. An IL-7- dependent rebound in thymic T cell output contributes to the bone loss induced by estrogen deficiency. Proc. Natl. Acad. Sci. USA, 2005, vol. 102, no. 46, pp. 16735-16740.

55. Nakamura I., Jimi E. Regulation of osteoclast differentiation and function by interleukin-1. Vitam. Horm., 2006, vol. 74, pp. 357-370.

56. Takayanagi H. Osteoimmunology and the effects of the immune system on bone. Nat. Rev. Rheumatol., 2009, vol. 5, no. 12 , pp. $667-676$. DOI: $10.1038 /$ nrrheum.2009.217.

Received: 02.07.2019

\section{Information about the author:}

Svetlana V. Bragina, M.D., Ph.D, Assistant Professor

Northern State Medical University, Arkhangelsk, Russia,

Email: svetabragina69@mail.ru 